\title{
Placental chorioangioma with adverse maternal and fetal outcome - a case report
}

\author{
Sindhujha Sekar, Valsa Diana \\ Correspondence: Valsa Diana, Senior Consultant, Department of Obstetrics and \\ Gynecology, Rajiv Gandhi government women and children hospital, Puducherry. India; \\ Email - valsadiana@gmail.com
}

Distributed under Creative Commons Attribution-Share Alike 4.0 International.

\begin{abstract}
Chorioangioma of placenta is the most common benign tumor of placenta, with an incidence of approximately $1 \%$ of all pregnancies. Large chorioangiomas have dismal prognosis due to their high association with maternal and fetal complications. A 27 year old gravida 2 abortion 1 at 29 weeks 3 days gestational age came with history of decreased fetal movements, decreased urine output and swelling of legs for one week. On admission, ultrasound showed an intrauterine fetal demise at 27 weeks 3 days gestational age and polyhydramnios. The placenta was enlarged and a well defined heteroechoic area of $6 \times 6.1 \mathrm{~cm}^{2}$ noted within it. Patient expelled macerated baby on day 2 of admission. The placenta weighed $1.3 \mathrm{Kgs}$ and was soft, friable and pale with $6 \times 5 \mathrm{~cm}^{2}$ lobulated mass within the placental substance. Histopathology showed chorioangioma of placenta.

Keywords: Placenta, chorioangioma, polyhydramnios, gestational hypertension, ultrasonography, intrauterine fetal death, tumor.
\end{abstract}

Chorioangioma is the most common benign nontrophoblastic tumor of placenta arising from chorionic tissue $^{1}$. Other names for chorioangioma are angiomyxoma and vascular hamartoma of placenta. An increased incidence rate of chorioangioma is associated with increased maternal age, hypertension, diabetes, female sex, first delivery and multiple pregnancies ${ }^{2-4}$. Large chorioangioma more than $5 \mathrm{cms}$ has unfavorable outcome on both mother and fetus ${ }^{5}$. Chorioangiomas have 30$50 \%$ perinatal mortality ${ }^{6}$. Prevalence of chorioangioma is $0.6 \%{ }^{7}$. Most are minute discovered only by sectioning and histological studies of placenta. Large or multiple chorioangiomas have an incidence of $1: 3500$ to $1: 16000$ births ${ }^{8}$. Placental chorioangioma causes chronic placental insufficiency resulting in fetal growth restriction, polyhydramnios, preterm labour, preeclampsia, fetal hemolytic anemia, fetal thrombocytopenia, cardiomegaly, placental abruption, congenital abnormalities and neonatal death due to cardiac failure ${ }^{9}$. With the advent of gray scale and color flow ultrasound in prenatal diagnosis these tumors can be detected antenatally ${ }^{10}$. Pregnancy needs to have regular surveillance.

\section{Case Report}

A 27 year old gravida 2 abortion 1 at 29 weeks 3 days gestational age referred from a private hospital with history of decreased fetal movements for 2 days, decreased urine output for one week and pedal edema for one week. In the present pregnancy, she had undergone an

Received: $6^{\text {th }}$ January 2018. Accepted: $24^{\text {th }}$ February 2018 .

Sekar S, Diana V. Placental chorioangioma with adverse maternal and fetal outcome - a case report. The New Indian Journal of OBGYN. 2018; 5(1): 51-55. 
ultrasound in early pregnancy that showed a single viable intrauterine fetus at 13 weeks of gestational age and was unremarkable. An anomaly scan at 23 weeks gestation also was unremarkable and the pregnancy continued till

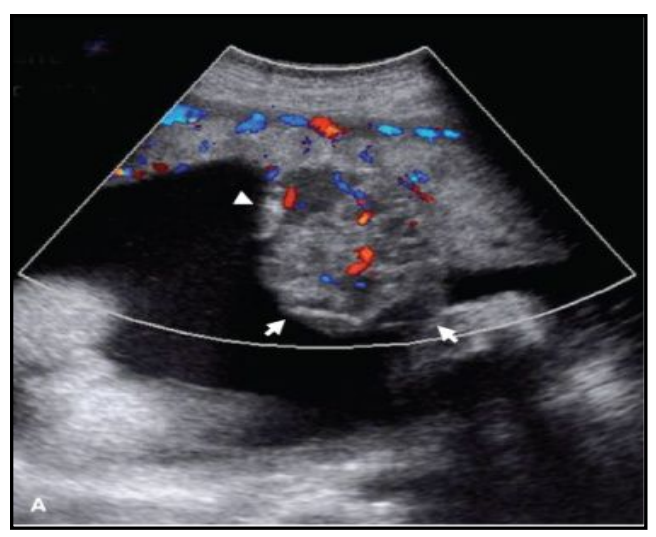

Figure 1: Antenatal ultrasound showing chorioangioma

28 weeks uneventfully. Subsequently on admission, USG carried out showed an intrauterine fetal demise at 27 wks 3 days gestational age with increased amount of liquor. The placenta was enlarged, posterior, upper segment showing grade one maturity. A well defined heteroechoic area $6 \times 6.1 \mathrm{~cm}^{2}$ noted within the placenta (Figure 1). An amniotic band was also seen separating abdomen from lower limbs of fetus. Impression was suggestive of a placental tumor, possibly a placental chorioangioma. On

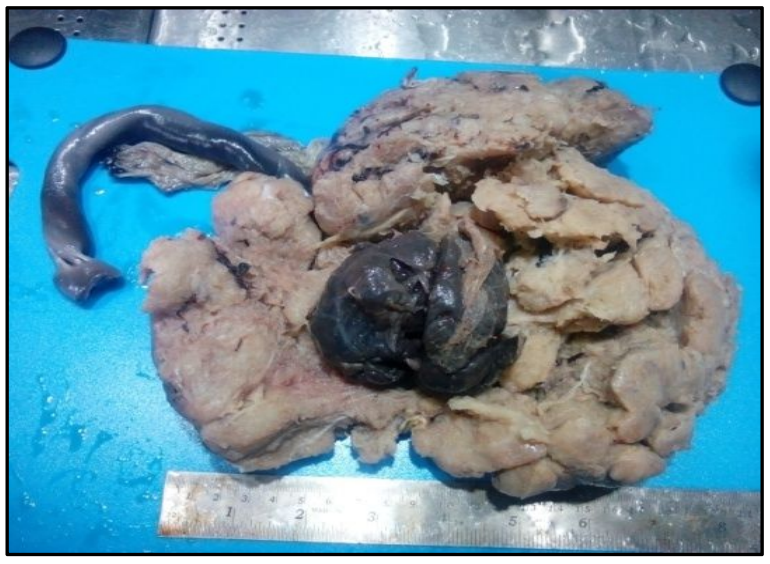

Figure 2: Macroscopic specimen of placenta chorioangioma examination, her vital signs were within normal limits except for a high BP of 140/90 mm of Hg. She also had bilateral pedal edema. Abdominal examination revealed a non tense, non tender, relaxed abdomen with a single fetus in longitudinal lie and cephalic presentation. Fetal heart sound could not be localized. Liquor seemed clinically increased. On per vaginal examination, her cervix was unaffected and external os closed. She was given further work up and necessary consents were taken. Her haematocrit, liver function tests and glucose tolerance tests were also within normal limits. VDRL was non reactive. Blood group was B positive. Antibiotics were given and tablet labetalol started.

Patient was induced by vaginal misoprostol and she delivered on day 2 of admission with 6 hours of labour. The baby was a stillborn, female $2.02 \mathrm{kgs}$ with maceration

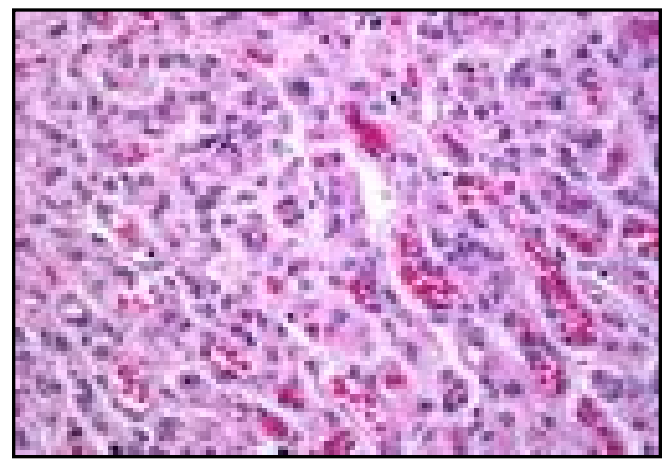

Figure 3: Histopathology showing numerous small capillaries

and generalized edema. Baby had cleft lip but no other gross congenital anomalies could be made out. The placenta weighed $1.3 \mathrm{Kgs}$ and was soft, friable and pale with lobulated mass $6 \times 5 \mathrm{~cm}^{2}$ within the placental substance (Figure 2). No retroplacental clot were seen. The three vessel umbilical cord with $30 \mathrm{cms}$ in length and $1 \mathrm{~cm}$ in diameter was placed in the centre. Thereafter the patient had mild postpartum hemorrhage managed initially with drugs but when it turned intractable, she was transfused with 2 units whole blood and two units fresh frozen plasma. Her postpartum period was uneventful and she was discharged after one week. Her histopathology showed numerous capillaries separated by thin stroma 
suggestive of placental chorioangioma (Figure 3). Discussion

Placental chorioangioma is a benign placental vascular tumor which has an incidence of approximately $1 \%$ in all pregnancies. Vascular tumors were first described by Clarke in 1798. These tumors have abnormal proliferation of vessels arising from the chorionic tissue. In this case the chorioangioma was $6 \times 5 \mathrm{~cm}^{2}$ and patient presented with gestational hypertension, polyhydramnios and intrauterine fetal death. Grossly these angiomas are nodular, fleshy lesions attached to the chorionic plate and often bulge from the fetal surface of placenta. In our case the mass was $6 \times 5 \mathrm{~cm}^{2}$ in diameter and was found within the substance of placenta. Nidhi Kataria et al ${ }^{11}$ reported a mass of $8 \times 7 \mathrm{~cm}^{2}$ in placenta. Serpil Aydogmus et al ${ }^{12}$ also reported a mass of $7 \times 6 \mathrm{~cm}^{2}$ in placenta with adverse fetal outcome.

Most of the cases were below 30years in previous studies e.g Nidhi Kataria et $\mathrm{al}^{11}$, Nabil Abdalla et $\mathrm{al}^{10}$, Manju Yadav et $\mathrm{al}^{2}$, Galimberte et $\mathrm{al}^{13}$. Our patient was also of 27 years of age. Time of diagnosis of chorioangioma was mostly between 25 to 30 weeks in previous studies ${ }^{2,10,11,13}$. In our case, chorioangioma was diagnosed at 29 weeks. Chorioangioma more than $5 \mathrm{cms}$ has adverse maternal and fetal outcome. All the previous studies report masses above $5 \mathrm{cms}$ similar to our patient who has a chorioangioma mass of $6 \times 5 \mathrm{cms}$.

Chorioangioma has a sex predilection for female babies which could be seen in previous case reports $9,10,13$ and in our case also. Our patient had associated gestational hypertension which was earlier reported in a case study by Galimberte et $\mathrm{al}^{13}$. Our case also had postpartum hemorrhage which had been reported previously in a case report by Manju Yadav et al ${ }^{2}$. Modes of delivery in cases of placental chorioangioma were mostly emergency caesarean section to prevent adverse maternal and fetal outcome.

Differential diagnosis for chorioangioma include placental teratoma, which is a cystic avascular solid mass with calcification or may be a placental hematoma but its echogenicity differs with time or may be a partial mole which has a diffuse pattern or may be myxoma which is often found on the maternal surface of placenta. ${ }^{11}$

Color doppler ultrasound plays an important role in the prenatal evaluation of solid placental masses. Close monitoring with doppler measurement of MCA - PSV, and looking for early signs of hyperdynamic circulation, are essential actions. Fetal ECHO detecting cardiomegaly is also important during the antenatal period. Early detection could prevent subsequent major complications, such as fetal death by antenatal interventions like in utero fetal blood transfusion and early delivery at a reasonable gestational age.

Small chorioangiomas (less than $5 \mathrm{~cm}$ in diameter) are inconsequential. Large placental chorioangioma may cause a variety of complications such as polyhydramnios, preterm delivery, abruption and placenta previa. Arteriovenous shunts in large chorioangiomas can impair the fetal circulation by increasing the venous return to the heart, causing tachycardia, cardiomegaly and hypervolaemia ${ }^{12}$. As a result, there is the possibility of high output cardiac failure, oedema, hydrops, stillbirth and intrauterine growth retardation. Anaemia, thrombocytopaenia, congenital anomalies or congestive cardiac failure may be seen in a neonate ${ }^{5}$. In our case, baby had associated cleft lip.

Pathogenesis of chorioangioma of placenta has many hypotheses like high altitude, hypoxia, elevated RBC, vascular growth factors, arteriovenous shunting and sequestration of RBCs and platelets which can lead to hemolysis, microangiopathic anemia and hydrops. Polyhydramnios is due to amniotic fluid exudate from walls of abnormal tumor vessels and mechanical obstruction of umbilical vein due to tumor. Post partum hemorrhage is due to rupture of tumor sinusoids causing sudden deterioration. Grayscale ultrasound with color doppler imaging shows a well defined echogenic complex vascular masses. Placental MRI is also safe in pregnancy. Histology has 3 patterns. Angiomatous pattern is most common with numerous small areas of endothelial tissue, capillaries and blood vessels surrounded by placental stroma. Cellular pattern has abundant endothelial cells within a loose scanty stroma. Degenerate pattern shows calcification, necrosis and hyalinization.

Our patient had gestational hypertension also. Hence it is necessary to stress the importance of suspecting early onset hypertension in cases of placental chorioangioma.

No treatment is superior to other. Existing prenatal treatment is supportive or definitive. Supportive treatment includes serial fetal intrauterine transfusions, 
amnioreduction, maternal transplacental pharmacotherapy with indomethacin, digoxin and steroids before 34 weeks for lung maturity. Definitive treatment includes endoscopic surgical devascularisation like ligation or clipping, fetoscopic laser ablation, embolisation, chemosclerosis with absolute alcohol injection and radiofrequency ablation of tumor vessels ${ }^{14}$. Therapy is contemplated only when there are USG features of fetal compromise and gestation is nonviable. Small asymptomatic tumors are managed expectantly, every month for small tumors and every 1-2 weeks for larger ones $^{14}$. Any time fetus can get distress and anytime fetal hydrops and congestive cardiac failure can occur. Our patient was an unbooked case with intrauterine fetal demise and delivered within 48 hours of admission and nothing much could be done.

\section{Conclusion}

The diagnosis and management of placental chorioangioma represents a stringent challenge due to its potentially serious antenatal complications adversely affecting pregnancy outcome. Early diagnosis, individualized assessment and regular follow up is necessary. Fetal doppler, fetal ECHO and antenatal ultrasound is recommended for early diagnosis and follow up of these cases. High fetal death in these cases warrants institutional and timely delivery. The above case demonstrates the need for awareness of such lesions.

\section{Conflict of interest: None. Disclaimer: Nil.}

\section{References}

1.Faes T, Pecceu A, Van Calenbergh S, Moerman P. Chorangiocarcinoma of the placenta: a case report and clinical review. Placenta. 2012; 33(8): 658-61.

2.Yadav M, Maheshwari M, Sharma S, Godha Z, Garg P, Sharma G. Chorioangioma of Placenta: A Rare Case of Near-Miss Mortality. The Journal of Obstetrics and Gynecology of India; 2017; 67(3): 224-26.

3.Hirata GI, Masaki DI, O'Toole M, Medearis AL, Platt LD. Color flow mapping and Doppler velocimetry in the diagnosis and management of a placental chorioangioma associated with nonimmune fetal hydrops. Obstet Gynecol. 1993; 81(5)): 850-53.
4.Guschmann M, Henrich W, Dudenhausen JW.

Chorioangiomas-new insights into a well-known problem. II. An immuno-histochemical investigation of 136 cases. J Perinat Med. 2003; 31:170-75.

5.Zanardini C, Papageorghiou A, Bhide A. Giant placental chorangioma: natural history and pregnancy outcome. Ultrasound Obstet Gynecol. 2010; 35: 332-36.

6.Kirkpatrick AD, Podberesky DJ, Gray AE, McDermott JH. Placental chorioangioma. Radiographics. 2007; 27(4):118790.

7.Kodandapani S, Shreshta A, Ramkumar V, Rao L. Chorioangioma of Placenta: A Rare Placental Cause for Adverse Fetal Outcome. Case Reports in Obstetrics and Gynecology. 2012; 2012: 913878.

8.Esen UI, Orife SU, Pollard K. Placental chorioangioma: a case report and literature review. Br J Clin Pract. 1997; 51(3): 181-82.

9.Vaidyanathan G, Bai A, Perchani J, El Said H, Lakhtakia

R. Placental Chorioangioma: Usual Presentation and Alternate Treatment Options. Journal of Case Reports. 2017; 7(1): 30-32.

10.Abdalla N, Bachanek M, Trojanowski S, Cendrowski K, Sawicki W. Placental tumor (chorioangioma) as a cause of polyhydramnios: a case report. International Journal of Women's Health. 2014; 6: 955-59.

11.Kataria N, Singh A, Kamal P, Giant B. Placental chorioangioma:A rare case report. Journal of Clinical and Diagnostic Research. 2016; 10(4): ED03-ED04.

12.Aydogmus S, Seyhanli Z, Eris S, Aydogmus H, Yiğit SC, Kelekci S. A Large Placental Chorioangioma without an Adverse Perinatal Effect. International Journal of Case Report. 2015; 2015: Article ID 613512, 5 pages.

13. Galimberte A, Jain S. Placental chorioangioma as a cause of maternal hydrops syndrome. Journal of Obstetrics and Gynecology. 2000; 20(1): 91.

14.Kesrouani AK, Safi J, El Hajj MA. Rapid evolution of placental chorioangioma: natural progression and outcome. J Ultrasound Med. 2013; 32(3): 545-48.

Sindhujha Sekar ${ }^{1}$, Valsa Diana ${ }^{2}$

${ }^{1}$ Resident Doctor, ${ }^{2}$ Senior Consultanr, Department of Obstetrics and Gynecology, Rajiv Gandhi government women and children hospital, Puducherry, India. 